\title{
Genetic diversity detection of the domestic horse (Equus caballus) by genes associated with coat color
}

\author{
Detección de la diversidad genética del caballo doméstico \\ (Equus caballus) mediante genes asociados al color del pelaje
}

\author{
Luz Correa A, ${ }^{1 *}$ Biol, Cindy Reyes E, ${ }^{1}$ Biol, Enrique Pardo P, ${ }^{1} \mathrm{Ph} . \mathrm{D}$, \\ Teodora Cavadia M, ${ }^{1}$ M.Sc.
}

\begin{abstract}
${ }^{1}$ Universidad de Córdoba, Facultad de Ciencias Básicas, Departamento de Biología, Grupo de Investigación Genes. Carrera 6 No. 76-103. Montería, Colombia. *Correspondencia: luzaraujo65@ hotmail.com
\end{abstract}

Received: September 2014; Accepted: February 2015.

\begin{abstract}
Objective. To assess the population structure and genetic diversity in populations of domestic horse (Equus caballus) in the municipality Cienaga de Oro-Córdoba (Colombia). Materials and methods. Random sampling were conducted between August and October 2013, in adult animals on farms seven districts, which was carried out phenotypic characterization of each animal, based on autosomal markers encoding morphological Extension (E) , Agouti (A), Cream (C), White (W), Gray (G), Tobiano (TO), Overo (O) and Roan (RN). Population genetic parameters: allele frequency, genetic diversity, gene flow, Hardy-Weinberg equilibrium and genetic distance were calculated through the program POPGENE 1.31; the genetic structure was assessed using the program FSTAT v. 2.9.3.2. Results. 341 individuals were analyzed in the seven populations studied, where the Extension gene Was the MOST faq frequently as the Overo and Tobiano genes showed the lowest values. Insignificant values of genetic variability and population recorded a global level, likewise, low genetic differentiation among populations, accompanied by a high gene flow was obtained; an excess of heterozygotes at population and global level was observed; to this is added the presence of Hardy-Weinberg equilibrium in all populations relative to the markers studied and low genetic distance values were reported. Conclusions. The populations are highly genetically related, a situation that may result from the existing geographical proximity between them, favoring genetic exchange and the establishment of a metapopulation.
\end{abstract}

Key words: Horse, Ciénaga de Oro, Córdoba, heterozygosity (Source: MeSH).

\section{RESUMEN}

Objetivo. Evaluar la estructura poblacional y la diversidad genética en poblaciones de caballo doméstico (Equus caballus), en el municipio Ciénaga de Oro, Córdoba (Colombia). Materiales y métodos. Se realizaron muestreos aleatorios entre los meses de Agosto y Octubre del año 2013, en animales adultos presentes en las fincas de siete corregimientos, donde se llevó a cabo la caracterización fenotípica a cada animal, atendiendo a los marcadores autosómicos de codificación morfológica Extension (E), Agouti (A), Cream (C), White (W), Gris (G), Tobiano (TO), Overo (O) y Roan (RN). Los parámetros genéticos poblacionales: frecuencia alélica, diversidad genética, flujo génico, equilibrio Hardy-Weinberg y distancia génica, fueron calculados a través del programa PopGene 1.31; la estructura genética se evaluó mediante el programa FSTAT v. 2.9.3.2. Resultados. Se analizaron 
341 individuos en las siete poblaciones estudiadas, donde El marcador Extensión fue el de mayor frecuencia mientras los genes Overo y Tobiano presentaron los menores valores. Se registraron cifras poco significativas de variabilidad genética a nivel global y poblacional, así mismo, se obtuvo una escasa diferenciación genética entre las poblaciones, acompañado de un elevado flujo génico; se observó un exceso de heterocigotos a nivel poblacional y a nivel total, a esto se le suma la presencia de equilibrio Hardy-Weinberg en todas las poblaciones con relación a los marcadores estudiados y se reportaron valores bajos de distancia genética. Conclusiones. Las poblaciones se encuentran muy relacionadas genéticamente, situación que puede obedecer a la cercanía geográfica existente entre ellas, favoreciendo el intercambio genético y la constitución de una metapoblación.

Palabras clave: Caballo, Ciénaga de Oro, Córdoba, heterocigosidad (Fuente: MeSH).

\section{INTRODUCTION}

The domestic horse (Equus caballus) is a mammal of the Perissodactyla order and the Equiidae family; this species is characterized by having long and strong limbs, barrel type body covered by short hair, as well as a long neck that supports the moderately large head and a tail that extends until half the hindlimbs (1). This animal has been considered as one of the main domestic resources throughout human history, because its force, nobility and fidelity characteristics have been fundamental in the fight for freedom of mankind and the development of nations. Historically, Colombia has been a country with equine interest, and as such, there has been progress in understanding this important domestic resource with special emphasis in species related to the development of preventive sanitary and diagnostic schemes. However, there is a large gap in the genetic research field of the animal; therefore, a deeper study of this type should be conducted as a complement to the complete knowledge of the domestic horse (2).

The diversity of domestic species is considered an important component of the global biodiversity $(3,4)$, specially the variability of zoogenetic resources, which is considered a key element of all production systems since it provides the raw material for genetic improvement and the adaptation of changing circumstances, being local breeds a natural and irreplaceable reservoir of genetic variability. Therefore, their understanding is key for the possible planning of long-term sustainable conservation strategies (5). This situation has been reflected in the undertaking of genetic population studies in local breeds cattle $(6,7)$ and equine $(8)$ in order to design management plans oriented towards their protection and improvement.

Phenotypic markers are a valuable tool when analyzing the genetic structure of populations due to their large data contents, easy manipulation and identification and fast results (9). Important

\section{INTRODUCCIÓN}

El caballo doméstico (Equus caballus) es un mamífero del orden Perissodactyla y familia Equiidae; esta especie se caracteriza por tener extremidades largas y fuertes, cuerpo en forma de barril cubierto de pelos cortos, además de cuello largo que soporta la cabeza moderadamente grande y la cola se extiende hasta la mitad de las extremidades posteriores (1). Este animal es considerado como uno de los principales recursos domésticos a lo largo de la historia de la humanidad, pues la fuerza, nobleza y fidelidad que lo caracterizan, han sido fundamentales en la lucha del hombre por la libertad y el desarrollo de los pueblos. Colombia históricamente ha sido un país con vocación equina, por lo que se ha avanzado en el conocimiento de este importante recurso doméstico, con especial énfasis en aspectos relacionados con el mejoramiento de los esquemas sanitarios preventivos y de diagnóstico, pero con un gran vacío en el campo de la investigación genética, lo que ameritan la profundización en este tipo de estudios como complemento al conocimiento íntegro del caballo doméstico (2).

La diversidad de las especies domésticas es considerada un importante componente de la biodiversidad global $(3,4)$, especialmente la variabilidad de los recursos zoogenéticos, considerada elemento clave en todos los sistemas de producción, ya que proporciona la materia prima para la mejora genética y la adaptación a las circunstancias cambiantes, siendo las razas de origen criollo un reservorio natural e irremplazable de variabilidad genética; por lo tanto, el conocimiento de ellas es clave para la posible planificación de estrategias de conservación sustentables a largo plazo (5), situación que se ha visto reflejada con la realización de estudios genético poblacionales en ganado bovino $(6,7)$ y equino (8) de raza criolla, con el fin de diseñar planes de manejo, orientados hacia su protección y mejoramiento. Los marcadores fenotípicos, constituyen una valiosa herramienta a la hora de analizar la 
studies in domestic populations of cats (9) and pigeons (10) have been conducted through the use of genes related to their coat color.

In light of the above, this research had the purpose of assessing the genetic degree of diversity and structure of populations in domestic horses (Equus caballus) in the municipality of Cienaga de Oro, Colombia.

\section{MATERIALS AND METHODS}

Study location. The study was conducted at the municipality of Cienaga de Oro (Cordoba), located at $8^{\circ} 53^{\prime}$ latitude north and $75^{\circ} 37^{\prime}$ latitude west of the Greenwich meridian. The town has an altitude of $13 \mathrm{~m}$ above sea level and an average temperature of $27^{\circ} \mathrm{C}$, with an area of $751 \mathrm{~km}^{2}$, of which $368 \mathrm{~km}^{2}$ are in rural areas. The town includes the villages of Berastegui, El Siglo, Los Mimbres, Pijiguayal, Las Palmitas, Punta de Yañez and San Antonio del Tachira.

Obtaining of data. Random sampling was conducted between August and October 2013 in adult animals that are the property of the farms in each of the studied populations. Phenotypic characterization of each animal was conducted, based on encoding morphological autosomal markers (Extension, Agouti, Cream, Gray, White, Tobiano, Overo, Roan). Lastly, photographic records were taken of each individual.

\section{Coat markers.}

Extension (E). This gene originates the black color in the horse when it is expressed in a dominant form (E), while in the recessive condition (e), the coat does not acquire this color (11).

Agouti (A). In this dominant condition (A), the gene causes the black coloring to extend to the hair, the tail and the lower part of the legs; in a recessive (a) form it does not cause any change in the horse's color (11).

Cream (C). The dominant gene (C) causes the solid color to dilute, which causes the color to clarify; while in its recessive presentation (c), it does not cause the color to dilute (11).

Gray (G). The dominant characteristic of the gene causes (G) to mix the white and black hair, giving a gray image; in its recessive condition (g), the horse does not show this coat color (11).

White (W). When the (W) gene appears the horse is totally white. This marker should be in a heterozygote condition ( $\mathrm{Ww}$ ) since the homozygosis is lethal; while in its recessive trait estructura genética de las poblaciones, debido a su gran contenido informativo, fácil manipulación e identificación y rápida obtención de resultados (9), llevándose a cabo importantes estudios en poblaciones domésticas de gatos (9) y palomas (10), mediante el empleo de genes relacionados con el color la capa.

A raíz de lo anteriormente expuesto la presente investigación tuvo como finalidad conocer el grado de diversidad y estructura genética en poblaciones de caballos domésticos (Equus caballus) en el municipio de Ciénaga de Oro, Córdoba, Colombia.

\section{MATERIALES Y MÉTODOS}

Sitio de estudio. El estudio se realizó en el municipio de Ciénaga de Oro (Córdoba), localizado a $8^{\circ} 53^{\prime}$ de latitud norte y $75^{\circ} 37^{\prime}$ de longitud al oeste del meridiano de Greenwich, presenta una altitud de $13 \mathrm{msnm}$, y una temperatura promedio de $27^{\circ} \mathrm{C}$, con una extensión de $751 \mathrm{Km}^{2}$, de los cuales $368 \mathrm{~km}^{2}$ corresponden a la zona rural, donde se muestrearon los corregimientos Berástegui, El Siglo, Los Mimbres, Pijiguayal, Las Palmitas, Punta de Yánez y San Antonio del Táchira.

Obtención de datos. Se realizaron muestreos aleatorios entre los meses de Agosto a Octubre del año 2013, a 341 animales adultos presentes en las fincas de cada población estudiada, donde se caracterizó fenotípicamente cada animal atendiendo a los marcadores autosómicos de codificación morfológica (Extensión, Agouti, Cream, Gris, White, Tobiano, Overo, Roan), por último se tomaron registros fotográficos de cada individuo.

\section{Marcadores del pelaje}

Extension (E). Este gen origina el color negro en el caballo cuando se expresa de forma dominante (E), mientras que en condición recesiva (e) el pelaje no adquiere este color (11).

Agouti (A). En condición dominante $(A)$ el gen provoca que la coloración negra se extienda a la crin, cola y parte inferior de las patas, de forma recesiva (a) no causa ningún cambio en el color de los caballos (11).

Cream (C). El gen de forma dominante (C) propicia la dilución del color sólido, lo que conlleva a un esclarecimiento del mismo, mientras que su representación recesiva (c), no causa dilución en el color (11).

Gris (G). En carácter dominante el gen provoca (G) una mezcla de pelos blancos y negros, dando 
(w), the horse can have another color $(11,12)$.

Tobiano (TO). In the dominant condition (TO), the horse has a series of white spots that cross the dorsal region until the belly, and even on the legs; in its recessive condition (to), this characteristic is not present (11).

Overo (0). Given that the $(0)$ gen is dominant, white spots are present from the ventral region towards the dorsal region; the spots are usually small and can be present on the legs and the case; in its recessive form (o) this gene does not cause changes in the normal color of the horses (11).

Roan (RN). The horse that carries the dominant gene (RN) presents in the body a mix of white hairs in any base color, except on the hair and the legs; in its recessive condition ( $r n)$, this characteristic is not present (11).

Statistical design. The estimation of allele frequency of each marker at a population and at a global level, as well as the genetic diversity measures established by Nei corresponding to the expected heterozygosis ( $\mathrm{He})$, expected heterozygosis of the total population $\left(\mathrm{H}_{\mathrm{T}}\right)$, genetic differentiation coefficient $\left(\mathrm{G}_{\mathrm{ST}}\right)$, genetic flow $(\mathrm{Nm})$, Hardy-Weinberg equilibrium and genetic distance among the populations, were estimated with the PopGene 1.31 program (13). The genetic structure of the population, observing the fixation indexes proposed by Wright: $\mathrm{F}_{\mathrm{IS}} \mathrm{F}_{\mathrm{IT}}$ and $\mathrm{F}_{\mathrm{ST}}$, was calculated using the FSTAT v. 2.9.3.2 program (14).

The dendrogram that represents the estimated values of the genetic distance was elaborated with the UPGMA (Unweighted Pair Group Methodwith Arithmetic Mean) method using the MEGA 5,2 program (15).

\section{RESULTS}

In the seven population studies a total of 341 individuals were analyzed and distributed as follows: Berástegui $(n=68)$, El Siglo $(n=67)$, Pijiguayal $(n=54)$, Punta de Yánez $(n=47)$, Las Palmitas $(n=46)$, Los Mimbres $(n=41)$ and San Antonio del Táchira $(n=18)$.

Allele frequencies. When calculating allelic frequencies for each population (Table 1), the Extension gene was the most frequent, especially in municipalities like San Antonio $(p=1.000)$, Las Palmitas $(p=0.744)$ and Los Mimbres $(p=0.729)$; in the first two municipalities the Agouti gene frequency was significant, being the second marker in terms of frequency. On the other hand, una imagen general de gris, en condición recesiva (g) el caballo no presenta esta coloración en su capa (11).

White (W). Al expresarse el gen (W) el caballo es totalmente blanco, este marcador debe encontrarse en condición heterocigoto ( $\mathrm{Ww}$ ) ya que en homocigosis es letal, mientras que de manera recesiva ( $w$ ) el caballo puede ser de otro color $(11,12)$.

Tobiano (TO). En condición dominante (TO) el caballo posee una serie de manchas blancas que se extienden desde la región dorsal hasta llegar al vientre, e incluso pueden posarse en las patas, en condición recesiva (to) no se expresa esta característica (11).

Overo (0). Al ser dominante este gen (O) se producen manchas blancas orientadas desde la región ventral hacia la dorsal, generalmente son pequeñas y pueden localizarse en las patas y la cara, este gen en forma recesiva (o) no causa cambios en el color normal de los caballos (11).

Roan (RN). El caballo portador del gen dominante (RN) presenta en el cuerpo una mezcla de pelos blancos en cualquier color de fondo, a excepción de la cabeza y las patas, en condición recesiva ( $r n)$ no se produce esta característica (11).

Diseño estadístico. La estimación de las frecuencias alélicas de cada marcador a nivel poblacional y global, así como las medidas de diversidad genética establecidas por $\mathrm{Nei}$ correspondientes a la heterocigosidad esperada (He), heterocigosidad esperada de la población total $\left(H_{T}\right)$, coeficiente de diferenciación genética $\left(G_{S T}\right)$, flujo génico $(\mathrm{Nm})$, equilibrio HardyWeinberg y la distancia genética entre las poblaciones, se estimaron a través del programa PopGene 1.31 (13), la estructura genética de las poblaciones, atendiendo a los índices de fijación propuestos por Wright: $F_{I S} F_{I T}$ y $F_{S T}$ se calculó mediante el programa FSTAT v. 2.9.3.2 (14).

La elaboración del dendrograma que representa los valores estimados de distancia genética se realizó a través del método UPGMA (Unweighted Pair Group Methodwith Arithmetic Mean) empleando el programa MEGA 5.2 (15).

\section{RESULTADOS}

En las siete poblaciones estudiadas se analizaron un total de 341 individuos distribuidos de la siguiente forma: Berástegui $(n=68)$, El Siglo $(n=67)$, Pijiguayal $(n=54)$, Punta de Yánez 
Table 1. Allele frequency of each marker in the studied populations.

\begin{tabular}{crrrcccccc}
\hline \multirow{2}{*}{ Populations } & \multicolumn{8}{c}{ Locus } \\
\cline { 2 - 8 } & $\mathbf{E}$ & $\mathbf{A}$ & $\mathbf{C}$ & $\mathbf{W}$ & $\mathbf{G}$ & TO & $\mathbf{O}$ & $\mathbf{R N}$ \\
\hline Pijiguayal & 0.66 & 0.38 & 0.09 & 0.00 & 0.15 & 0.00 & 0.00 & 0.03 \\
Mimbres & 0.72 & 0.36 & 0.00 & 0.00 & 0.19 & 0.00 & 0.00 & 0.00 \\
El Siglo & 0.59 & 0.36 & 0.05 & 0.00 & 0.13 & 0.00 & 0.01 & 0.01 \\
Las Palmitas & 0.74 & 0.53 & 0.07 & 0.00 & 0.08 & 0.00 & 0.00 & 0.00 \\
San Antonio & 1.00 & 0.66 & 0.09 & 0.00 & 0.06 & 0.00 & 0.00 & 0.03 \\
Punta de Yánez & 0.67 & 0.45 & 0.04 & 0.00 & 0.10 & 0.00 & 0.00 & 0.00 \\
Berástegui & 0.68 & 0.46 & 0.07 & 0.00 & 0.08 & 0.01 & 0.00 & 0.01 \\
\hline
\end{tabular}

E: Extension; A: Agouti; C: Cream; W: White; G: Gray; TO: Tobiano; O: Overo; RN: Roan

the White marker, responsible for the white coat, was not found in any municipality; while the Tobiano, Overo and Roan markers were found in some municipalities in very low frequencies. On the other hand, Los Mimbres was the area with the less number of genes reported (only 3 and 8) followed by Las Palmitas and Punta de Yánez, which presented only half the reported genes; while that El Siglo had the most number of markers.

At global level, the Extension gene was the marker with the most frequency, followed by Agouti and Gray (Table 2); by contrast, the Cream, Tobiano, Overo and Roan genes presented the markers with the least frequency.

Table 2. Total allele frequency of each phenotypic marker in the municipality of Cienaga de Oro.

\begin{tabular}{ccccccccc}
\hline & \multicolumn{10}{c}{ Locus } \\
\hline \multirow{3}{*}{ Total Population } & $\mathbf{E}$ & $\mathbf{A}$ & $\mathbf{C}$ & $\mathbf{W}$ & $\mathbf{G}$ & TO & $\mathbf{O}$ & $\mathbf{R N}$ \\
& 0.69 & 0.43 & 0.06 & 0.00 & 0.11 & 0.00 & 0.00 & 0.01 \\
\hline
\end{tabular}

E: Extension; A: Agouti; C: Cream; W: White; G: Gray; TO: Tobiano; O: Overo; RN: Roan.

Genetic diversity. In each one of the populations, the medium level of genetic variability was low (Table 3), being San Antonio the municipality with the least heterozygosis $\left(\mathrm{H}_{\text {and }}=0.0958\right)$. On the other hand, at the marker level, El Siglo and Pijiguayal were the municipalities that resulted having the largest diversity indexes with respect to the Extension gene. However, for the Agouti marker, Las Palmitas was the area with the largest degree of genetic diversity at a general level by obtaining a value of 0.4977 , followed by Berástegui ( $H_{\text {and }}=0.4964$ ) and Punta de Yánez $\left(H_{\text {and }}=0.4958\right)$ for the marker previously mentioned, which also presented the highest levels of genetic variability in all municipalities, except in El Siglo. Altogether, the Agouti marker presented the largest genetic diversity $(n=47)$, Las Palmitas $(n=46)$, Los Mimbres $(n=41)$ y San Antonio del Táchira $(n=18)$.

Frecuencias alélicas. Al calcular las frecuencias alélicas para cada población (Tabla 1) se obtuvo que el gen Extensión fue el más frecuente, especialmente en las poblaciones de San Antonio $(p=1.000)$, Las Palmitas $(p=0.744)$ y Los Mimbres $(p=0.729)$, en las dos primeras el gen Agouti se encontró de manera significativa, ubicándose como el segundo marcador en términos de frecuencia. Por otra parte, el marcador White, responsable de la capa blanca, no se encontró en ninguna de las poblaciones, mientras que en algunas de ellas los marcadores Tobiano, Overo y Roan fueron encontrados en frecuencias muy bajas. Por otro lado, la población Los Mimbres fue la zona con el menor número de genes reportados (sólo 3 de los 8 ) seguido de Las Palmitas y Punta de Yánez, quienes presentaron sólo la mitad, mientras que la población de El siglo sobresale, al contener la mayor parte de los marcadores.

A nivel global, el gen Extensión se ubicó como el marcador con la mayor frecuencia, seguido de Agouti y Gris (Tabla 2), en contraste, los genes Cream, Tobiano, Overo y Roan presentaron las menores frecuencias.

Diversidad genética. En cada una de las poblaciones el nivel medio de variabilidad genética fue bajo (Tabla 3 ) siendo la población de San Antonio la de menor heterocigosidad $\left(H_{e}=0.0958\right)$, por otro lado, a nivel de marcadores, las poblaciones El Siglo y Pijiguayal resultaron ser las de mayores índices de diversidad génica con respecto al gen Extension; sin embargo, la población de Las Palmitas para el marcador Agouti, se ubicó como la zona con el mayor grado de diversidad génica a nivel general, al presentar un valor correspondiente a 0.4977, seguido de Berástegui $\left(\mathrm{H}_{\mathrm{e}}=0.4964\right)$ y Punta de Yánez $\left(H_{\mathrm{e}}=0.4958\right)$ para el marcador antes mencionado, quien además presentó los niveles más altos de variabilidad genética en todas las poblaciones a excepción de El Siglo. En conjunto, el marcador Agouti presentó el mayor valor de diversidad genética seguido del gen Extensión, cuyo índice fue significativamente superior a los registrados por el resto de los marcadores (Tabla 4), en promedio el nivel de variabilidad genética en la población total fue de 0.1542 . Con relación al test de equilibrio Hardy-Weinberg, a nivel general las poblaciones reportaron equilibrio, de igual manera sucedió para todos los marcadores.

Diferenciación genética y flujo génico. El nivel de diferenciación genética en la población de Ciénaga de Oro fue muy bajo (0.0452), lo 
Table 3. Nei's (1973) genetic diversity index in each population through expected Heterozygosis $\left(\mathrm{H}_{\mathrm{e}}\right)$ for each marker.

\begin{tabular}{|c|c|c|c|c|c|c|c|c|}
\hline \multirow{2}{*}{ Populations } & \multicolumn{7}{|c|}{ Locus } & \multirow{2}{*}{ Average } \\
\hline & E & $\mathbf{A}$ & C & G & Tо & $\mathbf{0}$ & $\mathbf{R N}$ & \\
\hline Pijiguayal & 0.44 & 0.47 & 0.16 & 0.25 & 0.00 & 0.00 & 0.05 & 0.17 \\
\hline Mimbres & 0.39 & 0.46 & 0.00 & 0.30 & 0.00 & 0.00 & 0.00 & 0.14 \\
\hline El Siglo & 0.48 & 0.46 & 0.10 & 0.22 & 0.01 & 0.01 & 0.03 & 0.17 \\
\hline Las Palmitas & 0.38 & 0.50 & 0.13 & 0.15 & 0.00 & 0.00 & 0.00 & 0.14 \\
\hline San Antonio & 0.00 & 0.44 & 0.16 & 0.11 & 0.00 & 0.00 & 0.05 & 0.09 \\
\hline Punta de Yánez & 0.44 & 0.49 & 0.08 & 0.18 & 0.00 & 0.00 & 0.00 & 0.15 \\
\hline Berástegui & 0.43 & 0.50 & 0.13 & 0.15 & 0.03 & 0.00 & 0.01 & 0.16 \\
\hline
\end{tabular}

E: Extension; A: Agouti; C: Cream; W: White; G: Gray; TO: Tobiano; O: Overo; RN: Roan.

value followed by the Extension plan, whose index was significantly higher than the indexes registered by the rest of the markers (Table 4 ). On average, the genetic variability level on the total population was 0.1542 . With respect to the Hardy-Weinberg equilibrium test, at a general level the municipalities reported equilibrium. This also happened for all markers.

Genetic differentiation and genic flow. The genetic differentiation level in Cienaga de Oro was very low $(0.0452)$, which indicates that approximately $4.5 \%$ of the variation detected is due to differences between the populations; therefore, the seven populations were not significantly different for the studied markers and suggest that all these are considered as a single population.

In contrast, the higher value of the genetic flow (10.5569) indicates that the populations keep a considerable degree of genetic exchange, assuming a total of ten migrants per generation. Also, the number obtained is higher than 1 and 4 , which indicates that the populations behave like a metapopulation.

Population structure. The negative numbers in each marker and in average $(-0.0733)$ for the $F_{\text {IS }}$ coefficient (Table 5), show an excess of heterozygotes of the individuals with respect to each population and therefore, the absence of consanguinity is assumed. With values of -0.0064 for the Cream marker up to $-0,3968$ for the Tobiano gene, in relation to the $\mathrm{F}_{\mathrm{IT}}$ statistical, the average value $(-0.0246)$ reflects an excess of heterozygotes of the individuals with respect to the total population, covering values of -0.026 to -0.3809 for the Gray and Overo markers, respectively. It is important to highlight that the average $F_{I S}$ and $F_{I T}$ values do not move away too
Table 4. Total Heterozygosis and Hardy-Weinberg equilibrium test for each marker in the municipality of Ciénaga de Oro.

\begin{tabular}{ccccccccc}
\hline Locus & E & A & C & G & TO & O & RN & Average \\
\hline $\mathrm{H}_{\mathrm{T}}$ & 0.39 & 0.49 & 0.11 & 0.191 & 0.001 & 0.00 & 0.02 & 0.15 \\
$\mathrm{H}-\mathrm{W}$ & 0.00 & 0.00 & 0.001 & 0.001 & 0.00 & 0.00 & 0.00 & \\
\hline E: Extension; A: Agouti; C: Cream; W: White; G: Gray; TO: Tobiano; \\
O: Overo; RN: Roan.
\end{tabular}

cual indica que aproximadamente el $4.5 \%$ de la variación detectada se debe a diferencias entre las poblaciones, por lo tanto, las siete poblaciones no fueron significativamente diferentes para los marcadores estudiados y sugiere que todas ellas se mantienen como una sola población.

En contraste, el elevado valor de flujo génico (10.5569) permite suponer que las poblaciones mantienen un grado considerable de intercambio genético, asumiéndose un total de diez migrantes por generación, además la cifra obtenida resultó ser mayor que 1 y 4 , lo que indica que las poblaciones se comportan como una metapoblación.

Estructura poblacional. Las cifras negativas en cada marcador y en promedio $(-0.0733)$ para el coeficiente $\mathrm{F}_{\mathrm{IS}}$ (Tabla 5 ) reflejan un exceso de heterocigotos de los individuos con respecto a cada población y por lo tanto se asume ausencia de consanguinidad, con valores de -0.0064 para el marcador Cream hasta -0.3968 para el gen Tobiano, con relación al estadístico $\mathrm{F}_{\mathrm{IT}}$, el valor promedio (-0.0246) refleja un exceso de heterocigotos de los individuos con respecto a la población total, abarcando valores de -0.026 a -0.3809 para los marcadores Gris y Overo respectivamente. Es importante resaltar que los valores promedio de $F_{I S}$ y $F_{I T}$ no se alejan demasiado de cero, por lo que se asume que la población global está cerca del equilibrio Hardy-Weinberg. Por otro lado el valor promedio de $\mathrm{F}_{\mathrm{ST}}$ resultó ser bajo, lo que indica la escasa diferenciación génica existente entre las poblaciones, cabe resaltar que un valor similar se registró para el coeficiente $\mathrm{G}_{\mathrm{ST}}$.

Distancia genética. La distancia genética entre las poblaciones fue baja, siendo Punta de Yánez y Berástegui las poblaciones más cercanas (Tabla 6), mientras que El Siglo y San Antonio resultaron ser las de mayor diferencia génica; cifra poco significativa, pues no superó el $4 \%$, en este contexto, la población de San Antonio presentó los mayores valores de distancia genética en comparación con el resto de las poblaciones. 
Table 5. Statistical $\mathrm{F}$ values for each marker in a global population.

\begin{tabular}{cccc}
\hline Markers & $\mathbf{F}_{\mathbf{I S}}$ & $\mathbf{F}_{\mathbf{I T}}$ & $\mathbf{F}_{\mathbf{S T}}$ \\
\hline Extension & -0.1586 & -0.0743 & 0.0728 \\
Agouti & -0.0345 & 0.0101 & 0.0431 \\
Cream & -0.0064 & 0.0073 & 0.0136 \\
Gray & -0.0448 & -0.026 & 0.0181 \\
Tobiano & -0.3968 & -0.375 & 0.0156 \\
Overo & -0.3809 & -0.3809 & 0 \\
Roan & 0.0681 & 0.0807 & 0.0134 \\
Average & -0.0733 & -0.0246 & 0.0453 \\
\hline
\end{tabular}

much from zero; therefore, it is assumed that the global population is close to the Hardy-Weinberg equilibrium. On the other hand, the average $F_{S T}$ value was low, which indicates the minor genetic differentiation that exists in other populations. It is worth noting that a similar value was recorded for the $G_{S T}$ coefficient.

Genetic distance. The genetic distance between populations was low, being Punta de Yánez and Berástegui the closest populations (Table 6), while El Siglo and San Antonio were the populations with the highest genetic differentiation; the number was not very significant since it did not surpass $4 \%$. In this context, San Antonio presented the highest genetic distance values in comparison with the rest of the populations.

Considering the reported genetic distance values in the dendrogram (Figure 1), it can be observed that Punta de Yánez and Berástegui were the populations that were the closest and to which Las Palmitas is associated to. In relation to Pijiguayal and El Siglo, there is a considerable proximity, and also, they have a close relation with Los Mimbres. On the other hand, San Antonio was the farthest population from the other populations, but with an insignificant distance value, which allows to deduce that the populations altogether are very related.

\section{DISCUSSION}

The elevated frequency of the Extension gene in all populations can be due to the hypothesis proposed by several authors (16), which is based on the fact that the allele variations that make more melanin colors (dark) possible, are favored in the comparison with those colors with lighter tones. Also, it has been demonstrated that the absorption capacity of calorie radiation is more frequent in animals with dark coat than in those animals with lighter coats (17). This allows assuming that darker horses are better adapted to prevailing conditions in tropical climates, considering
Table 6. Genetic distance matrix (Nei, 1972) among populations.

\begin{tabular}{cccccccc}
\hline Population & $\mathbf{1}$ & $\mathbf{2}$ & $\mathbf{3}$ & $\mathbf{4}$ & $\mathbf{5}$ & $\mathbf{6}$ & $\mathbf{7}$ \\
\hline $\mathbf{1}$ & ----- & & & & & & \\
$\mathbf{2}$ & 0.0020 & ----- & & & & & \\
$\mathbf{3}$ & 0.0011 & 0.0037 & ----- & & & & \\
$\mathbf{4}$ & 0.0054 & 0.0071 & 0.0079 & ----- & & & \\
$\mathbf{5}$ & 0.0289 & 0.0277 & 0.0375 & 0.0117 & ----- & & \\
$\mathbf{6}$ & 0.0016 & 0.0033 & 0.0022 & 0.0018 & 0.0220 & ----- & \\
$\mathbf{7}$ & 0.0018 & 0.0042 & 0.0027 & 0.0015 & 0.0208 & 0.0002 & ----- \\
\hline
\end{tabular}

1: Pijiguayal; 2: Los Mimbres; 3: El Siglo; 4: Las Palmitas; 5: San Antonio; 6: Punta de Yánez; 7: Berástegui.

Atendiendo a los valores de distancia genética reportados en el dendrograma (Figura 1 ) puede apreciarse que las poblaciones de Punta de Yánez y Berástegui se ubicaron como las menos lejanas y a las cuales se asocia la población de las Palmitas. Con relación a las poblaciones de Pijiguayal y El Siglo, se destaca entre ellas una considerable cercanía, quienes a la vez, mantienen una estrecha relación con Los Mimbres. Por otro lado, la población de San Antonio se mantuvo alejada de las demás, pero con un valor de distancia poco significativo, que permite deducir que las poblaciones en conjunto están muy relacionadas.

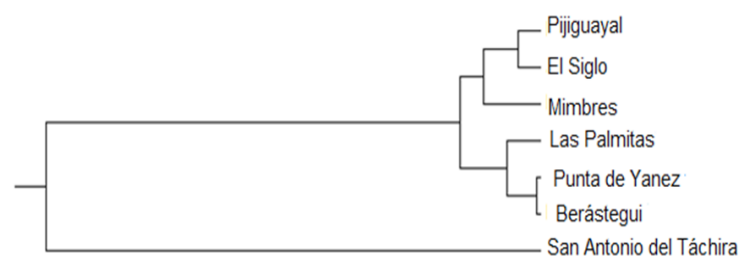

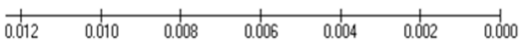

Figure 1. Dendrogram based in genetic distances (Nei, 1972) among the municipalities of the town of Cienaga de Oro, obtained by the UPGMA method.

\section{DISCUSIÓN}

La elevada frecuencia del gen Extension en todas las poblaciones puede obedecer a la hipótesis propuesta por varios autores (16) la cual se fundamenta en el hecho de que las variantes alélicas que posibilitan las coloraciones más melánicas (oscuras) se ven favorecidas en comparación con aquellas responsables de las tonalidades claras, además se ha demostrado que la capacidad de absorción de radiación calórica es más eficiente en animales de capa oscura que en aquellos de tonalidades claras (17), lo que permite suponer que los caballos oscuros, están mejor adaptados a las condiciones imperantes en el clima tropical, teniendo en cuenta que los equinos son animales que por lo general pastan la mayor parte del día. 
that equines are animals that usually spend the most part of the day grazing. On the other hand, the absence of white horses could be due to a particular condition that characterizes the White marker, but in homozygosis it causes the death of the animal (12). This fact explains the substantial reduction in the number of individuals that carry the gene.

The presence of the majority of markers in El Siglo, shows a large variety of genes available in the area. This situation is possibly due to geographic proximity between the studied populations and the surrounding municipalities, which favored the movement of migrants from one population to another and therefore, a considerable genetic exchange. This would explain the reduced number of genes reported in Los Mimbres, since this is the only population that does not have a direct contact with border populations. It's convenient to specify that even though the studied populations are in the Hardy-Weinberg equilibrium, the total absence of migration, mutation and selection cannot be assumed because the changes produced by these evolutionary forces in genetic frequencies take long periods of time. Therefore, to relate the adaptation and the coat color, as well as to highlight the importance of migration, are acceptable criteria in this research.

The low genetic diversity in each one of the populations and at a global level, together with a elevated genetic flow $(\mathrm{Nm}=10.5)$, reflects a close relationship that exists among populations since a high genetic exchange exceeds the effects of the genetic drift and prevents the local distinction (18). For this reason, the genetic differentiation degree between populations was low $\left(\mathrm{G}_{\mathrm{ST}}=0.0452\right)$. Genetic diversity as well as its close relationship with the genetic flow level in populations also influences significantly in genetic distances (19). Therefore, the distance values will be low as the diversity between populations is low. This indicates a direct relationship between these variables, which indicates that the low genetic diversity levels found were determining on the distance values recorded.

The excess of heterozygotes obtained through different fixation indexes $\left(F_{\text {IS }}\right.$ and $\left.F_{I T}\right)$ in each one of the populations, indicates that these present an almost homogeneous structure, which is a fact that would be attributable to the high genetic flow among them since the existence of a high exchange of genes prevents endogamy events within the populations (20) and provokes a reduction of homozygotes genotype. Also, this would be related to the
Por otro lado, la ausencia de caballos blancos, pudo deberse a la particular condición que caracteriza al marcador White, pues en homocigosis propicia la muerte del animal (12), hecho que explica la reducción sustancial en el número de individuos portadores del gen.

La presencia de la mayoría de los marcadores en la población de El Siglo, demuestra la gran variedad de genes disponibles en la zona, situación que posiblemente se atribuye a la cercanía geográfica existente entre las poblaciones en estudio y las aledañas al municipio, favoreciendo el movimiento de migrantes de una población a otra y por consiguiente, un considerable intercambio génico, esto explicaría el reducido número de genes reportados en la población de Los Mimbres, pues, es la única que no sostiene un contacto directo con las poblaciones fronterizas. Es conveniente precisar que aunque las poblaciones estudiadas se encuentran en equilibrio Hardy-Weinberg, no se puede asumir la completa ausencia de migración, mutación y selección, debido a que los cambios producidos por estas fuerzas evolutivas en las frecuencias génicas, toman largos períodos de tiempo, por lo tanto relacionar adaptación y color del pelaje, así como destacar la importancia de migración, son criterios aceptables en esta investigación.

La baja diversidad genética en cada una de las poblaciones y a nivel global, acompañado del elevado flujo génico $(\mathrm{Nm}=10.5)$, refleja la estrecha relación que existe entre las poblaciones, pues un alto intercambio genético supera los efectos de la deriva génica y previene la distinción local (18), razón por la cual, el grado de diferenciación genética entre las poblaciones fue bajo $\left(\mathrm{G}_{\mathrm{ST}}=0.0452\right)$. La diversidad genética además de la estrecha relación que sostiene con el nivel de flujo génico en las poblaciones, también influye de manera significativa en las distancias génicas (19), de tal modo que los valores de distancia serán pequeños mientras menor sea la diversidad entre las poblaciones, lo cual indica una relación directa entre estas variables, esto permite inferir que los bajos niveles de diversidad génica encontrados fueron determinantes sobre los valores de distancia registrados.

El exceso de heterocigotos obtenidos a través de los distintos índices de fijación $\left(\mathrm{F}_{\mathrm{IS}}\right.$ y $\mathrm{F}_{\mathrm{IT}}$ ) en cada una de las poblaciones, conduce a la suposición de que éstas presentan una estructura casi homogénea, hecho que sería atribuible al elevado flujo génico que hay entre ellas, dado que la existencia de un alto intercambio de genes previene eventos de endogamia al interior de las poblaciones (20), provocando por lo tanto una reducción de genotipos homocigotos, esto además, estaría relacionado con la probable aleatorización de los apareamientos, 
probable randomization of mating, a scenario expected in populations with Hardy-Weinberg equilibrium and that would facilitate the presence of null levels of consanguinity (21).

A crucial fact in terms of genetic distance is the size of the population since these two parameters have an indirect relation in which, as the population size decreases the higher the genetic distance with the rest of the populations (19). In this context, it could be said that San Antonio, the population with the smallest size, resulted in the most distance population from a genetic point of view. A possible response to the reduced number of recorded individuals is due to the topographic characteristics of the area, since this municipality is located in between a mountain chain with a woody vegetation, conditions that would limit the keeping of horses and considering that these horses usually graze in plain areas without exuberant vegetation (1). Resuming the issue of genetic distances, it is important to note that the distance model used in this study is based on Nei's proposal were the variation is attributed mainly to mutation and genetic drift, assuming an equilibrium in the two evolutionary forces (19); however, since these are populations that belong to a same species and that are developed in a same geographic area, the mutational phenomena is considered, being the genetic drift as the main cause for differentiation (20) of which effects, as mentioned before, are reduced when there is a high degree of genetic flow among the populations.

On the other hand, the great genetic proximity between Punta de Yánez and Berástegui corresponds to Lara et al (22) proposals in their work Psychotria acuminata, in which the genetic distance resulted to be directly proportional to the geography, since the populations mentioned herein are very close geographically, this situation is similar to Las Palmitas, which was closely related to the previously mentioned populations, specially with Berástegui, of which is very close in spatial terms; for Pijiguayal and El Siglo, although not close geographically, they were close from a genetic point of view, which could be due to the massive movement of horses through the main highway that is an important point of connection between both populations. It is worth remembering that this study was only conducted at a municipal level; therefore, a marked geographic distance as such cannot be considered since the most part of the genetic distance values does not exceed $1 \%$, which would indicate that the populations behave as one. escenario esperado en las poblaciones con equilibrio Hardy-Weinberg y que facilitaría la presencia de niveles nulos de consanguinidad (21).

Un hecho considerado crucial en términos de distancia genética, es el tamaño de la población, pues estos dos parámetros tienen una relación indirecta, en la cual, a medida que decrece el tamaño de una población mayor será la distancia genética de ésta con el resto de las poblaciones (19), en este contexto podría decirse que la población de San Antonio por ser la de menor tamaño poblacional, resulto ser la más distante desde el punto de vista genético, una posible respuesta al reducido número de individuos registrados, obedece a las características topográficas de la zona, pues esta población se encuentra en medio de una serranía acompañada de vegetación boscosa, condiciones que limitarían la tenencia de caballos, si se tiene en cuenta que son animales que por lo general pastan en lugares planos y desprovistos de vegetación exuberante (1). Retomando lo concerniente a distancias génicas, es oportuno resaltar que el modelo de distancia empleado en este estudio se basa en el propuesto por Nei, donde la variación es atribuida principalmente a la acción de la mutación y la deriva génica, asumiendo un equilibrio entre estas dos fuerzas evolutivas (19); sin embargo, por tratarse de poblaciones pertenecientes a una misma especie y que además se desenvuelven en un mismo ámbito geográfico, los fenómenos mutacionales no son tenidos en cuenta, considerándose la deriva génica como la principal causa de diferenciación (20), cuyos efectos como se mencionó anteriormente, son reducidos al existir un alto grado de flujo génico entre las poblaciones.

Por otro lado, la gran cercanía génica resultante entre las poblaciones de Punta de Yánez y Berástegui, concuerda con lo expuesto por Lara et al (22) en su trabajo con Psychotria acuminata, en donde la distancia genética resultó ser directamente proporcional a la geográfica, pues las poblaciones antes mencionadas mantienen una considerable cercanía geográfica, esta situación ocurre en igual medida para la población de Las palmitas, quien estuvo estrechamente relacionada con las poblaciones previamente descritas, en especial con Berástegui, de la cual es muy próxima en términos espaciales; para las poblaciones de Pijiguayal y El Siglo, a pesar de no ser muy cercanas geográficamente, si lo fueron desde el punto de vista genético, lo que pudo obedecer al desplazamiento masivo de los caballos a través de la carretera troncal, la cual constituye un importante centro de conexión entre ambas poblaciones. Es oportuno recordar que la ejecución de este estudio se centró sólo a nivel municipal, por tal motivo no puede hablarse de una marcada distancia 
The insignificant values of genetic variability, together with a high degree of genetic flow, allow to infer that the populations that are genetically very related and that behave as a metapopulation is situation that is attributed to geographic proximity of all the populations from a structural point of view and indicates the need to introduce new individuals from external populations, in order to increase the genetic diversity levels and to facilitate the heterogeneity in terms of the population's structure. geográfica como tal, teniendo en cuenta además, que la mayor parte de los valores de distancia genética no superaron el $1 \%$, lo que indicaría que las poblaciones se comportan como una sola.

Los valores poco significativos de variabilidad genética, acompañado del elevado grado de flujo génico, permite inferir que las poblaciones se encuentran muy relacionadas genéticamente y se comportan como una metapoblación, situación a la cual se atribuye la aproximación de todas las poblaciones desde el punto de vista estructural, lo que indica la necesidad de introducir nuevos individuos provenientes de poblaciones externas, con el fin de aumentar los niveles de diversidad genética y facilitar la heterogeneidad en términos de estructura poblacional.

\section{REFERENCES}

1. Álvarez-Romero J, Medellín RA. Equus caballus. Vertebrados superiores exóticos en México: diversidad, distribución y efectos potenciales. Instituto de Ecología, Universidad Nacional Autónoma de México; 2005.

2. Naranjo S. Evaluación citogenética del caballo criollo colombiano. [Tesis de Maestría]. Medellín: Facultad de ciencias, Universidad Nacional de Colombia; 2012.

3. Ajmone-Marsan P. A global view of livestock biodiversity and conservation - Globaldiv. Anim Genet. 2010; 41(Supl 1):1-5.

4. Boettcher $P$, Tixier-Boichard $M$, Toro $M$, Simianer $H$, Eding $H$, Gandini $G$, et al. Objectives, criteria and methods for using molecular genetic data in priority setting for conservation of animal genetic resources. Anim Gene 2010; 41(Supl 1):64-77.

5. Giovambattista G, Rogberg MA, Ripoli M, Villegas E, Díaz S, Posik D, et al. La genética molecular de bovinos y equinos criollos en los albores del siglo XXI. J Basic Appl Genet 2010; 21(Supl 1):1-14.

6. Piedrahíta A, Posso A, Muñoz J, Alvarez L. Variabilidad genética de Hartón del Valle mediante RAM. Facultad de Ciencias Agropecuarias, Universidad Nacional de Colombia; 2007.

7. Bejarano D, Pedraza A, Rocha J, Martínez R. Variabilidad genética en subpoblaciones comerciales de la raza criolla colombiana Romosinuano. Rev Corpoica 2012; 13(Supl 1): 97-107.
8. Jimenez L, Cañon J, Sanchez C, Sandoval F, Gomez A. Análisis de la variabilidad genética en caballos criollos llaneros colombianos mediante la utilización de microsatélites. Rev Col Cienc Pec 2007; 20(4):573-574.

9. Ruiz-Garcia M, Alvarez D, Shostell J. Population genetic analysis of cat populations from Mexico, Colombia, Bolivia, and the Dominican Republic: identification of different gene pools in Latin America. J Genet 2005; 84(Supl 1):147-171.

10. Čanády A, Mošanský L. Population size and plumage polymorphism of feral pigeon (Columba livia) from urban environment of Košice city (Slovakia). J Zool \& Ecol 2013; 23(2):104-110.

11. Bartolome E, Azor P, Gomez M, Peña F. La determinación genética del color de la capa en el caballo: Bases y aplicación al caballo de la raza Pottoka. Departamento de genética, Universidad de Córdoba (España); 2008.

12. Haase $B$, Brooks $S$, Schlumbaum A, Azor $P$, Bailey $E$, Alaeddine $F$, et al. Allelic heterogeneity at the equine KIT locus in dominant White (W) horses. PLoS Genet 2007; 3(11): 2101-2108.

13. Yeh FC, Yang RC, Mao J, Ye Z, Boyle TJ. POPGENE: the Microsoft Windows-based user-friendly software for population genetic analysis of co-dominant and dominant markers and quantitative traits. [Programa estadistico]. Version 1.31. Edmonton, Canadá: University of Alberta, Department of Renewable Resources; 1999. 
14. Goudet J. FSTAT: a Program to estimate and test gene diversity and fixation indices. [Programa estadístico]. Version 2.9.3.2. Lausanne, Switzerland: University of Lausanne, Department of Ecology \& Evolution; 2002.

15. Tamura K, Peterson D, Peterson N, Stecher G, Nei M, Kumar S. MEGA 5: Molecular evolutionary genetics analysis using maximum likelihood, evolutionary distance and maximum parsimony methods. Mol Biol Evol 2011; 28(10):2731-2739.

16. Jacquin L, Haussy C, Bertin C, Laroucau K, Gasparini, J. Darker female pigeons transmit more specific antibodies to their eggs than do paler ones. Biol J Linne Societ 2013; 108(3):647-657.

17. Gomes da Silva R, Guilhermino M, Façanha de Morais $D$. Thermal radiation absorbed by dairycows in pasture. Int J Biometeorol 2010; 54(Supl 1):5-11.

18. Piñero $D$, Barahona $A$, Eguiarte $L$, Rocha A, Salas R. La variabilidad genética de las especies: Aspectos conceptuales y sus aplicaciones y perspectivas en México. Conabio 2008; 1(Supl 1):415-435.
19. Demarchi D. Microsatélites, distancias genéticas y estructura de poblaciones nativas Sudamericanas. Rev Arg Antropol Biol 2009; 11(Supl 1):73-88.

20. Cortés O. Análisis de la variabilidad genética en la raza bovina de lidia utilizando información molecular. [Tesis doctoral]. Madrid: Universidad Complutense de Madrid; 2008.

21. Aranguren-Méndez J, Román R, Villasmil Y, Chirinos Z, Romero J. Componentes de varianza y parámetros genéticos para características de crecimiento en animales mestizos de doble propósito. Rev Científica FCV-LUZ 2006; 16(1):55-61.

22. Lara A, Valverde R, Rocha O, Gómez L. Variabilidad y diferenciación genética en cuatro poblaciones de la planta medicinal Psychotria acuminata en Costa Rica. Agron Costarr 2003; 27(2):29-42. 